\title{
The Novel as Social SatiRe: 60 Years LATER, THE WIND DONE GONE AND THE LIMITATIONS OF FAIR USE
}

\author{
DILAN THAMPAPILLAI*
}

The absence of the doctrine of fair use from Australian copyright law has been a bone of contention in Australia after the Australia-United States Free Trade Agreement (FTA). As the Australian government reformed the Copyright Act 1968 (Cth) in the aftermath of the FTA it eschewed the option of adopting fair use. Instead, Australia chose to incorporate a version of fair use into its existing fair dealing framework. Accordingly, the Copyright Amendment Act 2006 (Cth) inserted ss 41A and 103AA into the Copyright Act. These provisions provide that a fair dealing with a copyright protected work does not constitute an infringement if it is done for the purposes of parody or satire. These provisions codify part of the ratio of the United States Supreme Court in the seminal case of Campbell v Acuff Rose Music. However, the parameters of these new provisions are unexplored and the sparse nature of fair dealing jurisprudence means that the true meaning of the provisions is unclear. Moreover, two cases from the United States, SunTrust Bank v Houghton Mifflin and Salinger v Colting, underline just how important it is to have legal rules that protect literary 're-writes'. Both cases involved authors using an original novel to 'write back' to the original author and the broader culture. 'Writing back' or the 're-write' has a firm basis in literature. It adds something invaluable to our culture. The key question is whether our legal landscape can allow it to flourish. This paper examines the interaction between fair use and literary re-writes.

\section{INTRODUCTION}

Much has been made of the absence in Australian law of the United States' fair use doctrine. ${ }^{1}$ However, the fair use doctrine is far from the complete panacea that its advocates contend. In the United States fair use could not save Frederick Colting's novel 60 Years Later $(60 \mathrm{YL})$ from the claim that it infringed

\footnotetext{
*BA, LLB (ANU), M Com (USYD), LLM Cornell; Lecturer, School of Law, Deakin University.

${ }^{1}$ In 2005 in response to stakeholder pressure the Commonwealth government instituted the Fair Use Inquiry. See Attorney-General's Department, 'Fair Use and Other Copyright Exceptions: An Examination of Fair Use, Fair Dealing and Other Exceptions in the Digital Age' (Issues Paper, 5 May 2005). The result of that inquiry brought about the amendments to the Copyright Act 1968 (Cth) contained in the Copyright Amendment Act 2006 (Cth). More recently the Australian Law Reform Commission (ALRC) has again mooted the notion of including fair use in Australian copyright law. See ALRC, Copyright and the Digital Economy, Issues Paper No 42 (2012) 71-9.
} 
JD Salinger's Catcher in the Rye. ${ }^{2}$ Similarly, even though Houghton Mifflin succeeded in having the $11^{\text {th }}$ Circuit lift the injunction against publishing Alice Randall's The Wind Done Gone (TWDG) it was far from clear that fair use would protect the novel from the contention that it infringed Gone With The Wind (GWTW). Yet, both Randall and Colting's works embody a literary tradition of 'writing back' to power and to society. Randall's novel exposed the racism that lay at the heart of GWTW by retelling the original novel from the perspective of a slave. Colting's novel explored the themes of fame and reclusiveness by engineering a fictitious meeting between Salinger and his creation Holden Caulfield. These are the types of works that a flourishing culture would want to protect from claims of copyright infringement.

In SunTrust Bank $v$ Houghton Mifflin ${ }^{3}$ the $11^{\text {th }}$ Circuit found that Randall's novel TWDG was sufficiently transformative to warrant fair use protection. ${ }^{4}$ In making its decision the $11^{\text {th }}$ Circuit drew upon the landmark Supreme Court decision of Campbell v Acuff-Rose $e^{5}$ in which the Supreme Court found that 2Live Crew's version of Roy Orbison's Oh, Pretty Woman was a parody that was a transformative fair use of the latter's copyright protected work. In making this decision the Supreme Court put forward transformative use and parody as the key concepts that would create legal space for novels like TWDG and Colting's $60 Y L$. Indeed, were it not for the Supreme Court's decision in Campbell, Houghton Mifflin might not have decided to publish TWDG. In turn were it not for both Campbell and the $11^{\text {th }}$ Circuit's decision in SunTrust, Colting might not have decided to write 60YL or it might not have been published. Fair use sets out the legal infrastructure that allows for creative and commercial decisions. In turn this makes our culture richer by providing us with more cultural products from which to choose.

This paper deals with the fair use and the idea of the novel as social commentary. It begins from the premise that certain types of novels will need to copy or borrow from other literary traditions or works in order to make their point. ${ }^{6}$ This can be done through novels that are either parodies or satires. The difference between parody and satire has been a controversial issue in the United States. However, while fair use has made a distinction between satire and parody, ${ }^{7}$ Australia has not seen fit to make that distinction. ${ }^{8}$ Similarly, I feel

\footnotetext{
${ }^{2}$ Salinger $v$ Colting 641 F Supp 2d 250 (SDNY, 2009); Salinger v Colting 607 F 3d $\left(2^{\text {nd }}\right.$ Cir, 2010).

${ }^{3} 268$ F 3d 1257 (11 ${ }^{\text {th }}$ Cir, 2001).

${ }^{4}$ Ibid.

${ }^{5} 510$ US 569 (1994) ('Campbell').

${ }^{6}$ Campbell, 510 US 569, 580-1 (1994).

${ }^{7}$ See Campbell, 510 US 569, 580 (1994). Also, Walt Disney Productions v The Air Pirates, 581 F $2 d 751$ ( $9^{\text {th }}$ Cir, 1978) where the $9^{\text {th }}$ Circuit held that the existence of satirical elements within an
} 
that the distinction between satire and parody is unhelpful in this context. All too often art blurs the line between satire and parody and there is something artificial about law's attempts to maintain the divide. ${ }^{9}$ In Campbell, Souter J elucidated the difference between satire and parody:

Parody needs to mimic an original to make its point, and so has some claim to use the creation of its victim's (or collective victims') imagination, whereas satire can stand on its own two feet and so requires justification for the very act of borrowing. ${ }^{10}$

While that is a neat statement of the difference between satire and parody in the context of copyright law, in practice it has proved much harder to maintain the distinction. For example, Randall's novel TWDG, which was protected as fair use by the $11^{\text {th }}$ Circuit, both parodies Mitchell's novel and satirises the South. ${ }^{11}$ That said, in fair use cases parodies have been protected even where they contained elements of criticism directed at the broader society, which sat quite outside any parody of the 'target' work. ${ }^{12}$ While there appears to be little difficulty in constructing a legal rule such that a derivative work may be a fair use even though it contains elements of satire whereas a pure satire cannot be a fair use, such a rule presumes that a bright line can be drawn between a parody and a satire. If that presumption does not hold true then the efficacy of the rule falters.

impugned work would not prevent it from being a fair use parody. The Court stated at 758 : '[W]e do not regard it as fatal ... that the "Air Pirates" were parodying life and society in addition to parodying the Disney characters. Such an effect is almost an inherent aspect of any parody. To the extent that the Disney characters are not also an object of the parody, however, the need to conjure them up would be reduced if not eliminated.' In Elsmere Music Inc $v$ National Broadcasting Co, 482 F Supp 741 (SD NY, 1980) the District Court held that both a satire and/or a parody could be fair use. However, in MCA Inc $v$ Wilson, 677 F $2 d 180$ ( $2^{\text {nd }} C i r$, 1981) the Court reaffirmed the position in Walt Disney. That is, a parody is a fair use and that provided that it takes aim at the original copyright protected work it will remain so even if it also makes broader points about society. See also Leibovitz v Paramount Pictures Co 137 F 3d 109 ( ${ }^{\text {nd }}$ Cir, 1998); Dr Seuss Enterprises v Penguin Books USA Inc 109 F3d 1394 (9 $9^{\text {th }}$ Cir, 1997) ('Dr Suess').

${ }^{8}$ See Copyright Act 1968 (Cth) ss 41A, 103AA.

${ }^{9}$ See Maree Sainsbury, 'Parody, Satire and Copyright Infringement: The Latest Addition to Australian Fair Dealing Law’ (2007) 12 Media and Arts Law Review 292. See also Anna Spies, 'Revering Irreverence: A Fair Dealing Exception for both Weapon and Target Parodies' (2011) 34 University of New South Wales Law Journal 1122, 1124.

${ }^{10}$ Campbell, 510 US 569, 580-1 (1994).

${ }^{11}$ This is not in itself fatal under fair use. See the discussion above $\mathrm{n} 7$ regarding Walt Disney and MCA Inc $v$ Wilson.

${ }^{12}$ See above $n 7$. 
Moreover, fair use in the United States is underpinned by the First Amendment. ${ }^{13}$ As has been noted by the Supreme Court in Harper \& Row Publishers Inc $v$ Nation Enterprises ${ }^{14}$ and Eldred $v$ Ashcroft (AttorneyGeneral), ${ }^{15}$ fair use is one of copyright's internal safety valves that helps maintain the balance between copyright law and the First Amendment in the United States. ${ }^{16}$ The linkage between fair use parodies and the free speech values of the First Amendment has been noted in American jurisprudence. In Dr Seuss, the $9^{\text {th }}$ Circuit stated:

Parody is regarded as a form of social and literary criticism, having a socially significant value as free speech under the First Amendment. ${ }^{17}$

Similarly, the $11^{\text {th }}$ Circuit drew on the First Amendment in finding Randall's novel a fair use parody. ${ }^{18}$ Notably, the $11^{\text {th }}$ Circuit in SunTrust referred to 'the shared principles of the First Amendment and copyright law'. ${ }^{19}$ Nevertheless, there does not seem to be any compelling reason to confine social criticism, or free speech generally, to parodies of specific works. If free speech is a powerful consideration in this context then restraining copyright protection in order to allow a social criticism that uses a particular work to make a broader point about society seems highly consonant with the notion of free speech and the debates that have long surrounded the First Amendment.

It is perhaps quite fortunate that Australia has sidestepped this somewhat counterproductive argument over parody and satire in copyright law. ${ }^{20}$ After all,

\footnotetext{
${ }^{13}$ United States Constitution amend I.

14471 US 539 (1985) ('Harper \& Row'). While Harper \& Row is certainly an appropriate precedent for the proposition that fair use is an internal safety valve for the First Amendment, the case is still troubling from a free speech perspective. Harper \& Row represented the high water mark of the market failure theory of fair use. See Neil Netanel, 'Locating Copyright within the First Amendment Skein' (2001) 54 Stanford Law Review 1, 21. Netanel said 'like the idea/expression dichotomy, fair use's protection of First Amendment interests has weakened markedly in recent decades. The watershed in fair uses's debilitation came in ... Harper \& Row Publishers, Inc v Nation Enterprises'. Netanel points to the obiter remarks in Harper \& Row that draw upon Wendy Gordon's article 'Fair Use as Market Failure: A Structural and Economic Analysis of the Betamax Case and its Predecessors' (1982) 82 Columbia Law Review 1600.

${ }^{15} 537$ US 186 (2003). Ginsburg J, delivering the opinion of the Court, stated at 220 citing both Harper \& Row and Campbell: 'The fair use defense affords considerable "latitude for scholarship and comment” ... and even for parody.' (Citations omitted).

${ }^{16}$ Melville Nimmer, 'Does Copyright Abridge the First Amendment Guarantees of Free Speech and Press?' (1970) 17 University of California Los Angeles Law Review 1180.

${ }^{17}$ Dr Seuss, 109 F 3d 1394 ( ${ }^{\text {th }}$ Cir, 1997).

${ }^{18}$ SunTrust, 268 F 3d 1257, 1277 (11 ${ }^{\text {th }}$ Cir, 2001).

${ }^{19}$ Ibid (emphasis added).

${ }^{20}$ This is particularly true if we add free speech as a consideration that weighs in favour of fair use in the case of parodic novels. Australian law has nothing akin to the First Amendment, other than the implied freedom of political communication contained in the Australian Constitution
} 
the task of deciding whether a putative infringement of copyright in the case of a satirical novel is either fair use or a fair dealing is nothing more complex than an exercise in proportionality. That is, it involves balancing one legal interest (copyright protection) against another (free use of that copyright for public benefit) and deciding which must be afforded priority over the other as justice and established legal principles require. ${ }^{21}$ This is a familiar legal task and it is difficult to locate within that any great need to identify whether the potentially infringing work takes aims at the original work, society in general, or both. What must be accepted then is that both parody and satire are exercises in free speech and the fact that they warrant a free use exception in copyright law suggests that the statutory monopoly that is copyright needs to be reconciled with democratic values. ${ }^{22}$

On a literary level this fits into a tradition of 'writing back' which in recent times has become rather pronounced in post-colonial literature and in the noncommercial world of fan fiction. For example, Jean Rhys' Wide Sargasso Sea was written as a prequel to Jane Eyre. Other obvious candidates in post-colonial literature for writing back are Vikram Seth's A Suitable Boy which draws on the works of Jane Austen and Salman Rushdie's Midnight's Children which takes elements from Charles Dickens' Great Expectations. Both of these works borrowed from earlier works which were out of copyright. While their takings may have been slender enough to warrant protection under fair use or fair dealing, they have engaged in the same form of writing back, albeit less directly, as Randall and Colting. Outside of post-colonial literature, Peter Carey wrote Jack Maggs, ostensibly telling the tale of Magwitch in Australia. Similarly, Tom Stoppard's play Rosencrantz and Guildenstern are Dead portrayed Hamlet from the perspective of two minor characters.

ss 7, 24. Indeed, Australia were to import fair use into its law there is an argument that it will lose something in translation in the absence of the First Amendment. At any rate, in the Second Reading Speech to the Copyright Amendment Act 2006 the then Attorney-General Philip Ruddock MP drew upon free speech in enacting ss 41A and 103AA of the Copyright Act: 'A further exception promotes free speech and Australia's fine tradition of satire by allowing our comedians and cartoonists to use copyright material for the purposes of parody or satire.' See Commonwealth, Parliamentary Debates, House of Representatives, 19 October 2006, 1-2 (Philip Ruddock, Attorney-General). Little has been made of the Attorney-General's reference to comedians and cartoonists and it is presumably an irrelevance. It is not suggested here that the exception is confined to comedy or cartoons. It is likely a reference to the Panel case, TCN Channel Nine Pty Ltd v Network Ten Pty Ltd [2002] FCAFC 146, in which the Channel Ten television show The Panel used copyright protected excerpts from Channel Nine as part of their comedic program.

${ }^{21}$ For a discussion of proportionality see Justice Kiefel, 'Proportionality — a Rule of Reason' (2012) 23 Public Law Review 85.

22 Sir Anthony Mason has recognised that copyright may imperil free speech if its boundaries extend too far. See Sir Anthony Mason, 'Public-Interest Objectives and the Law of Copyright' (1998) 9 Journal of Law and Information Science 7, 11. 
This paper examines fair use, literary re-writes and the broader legal policy question of whether to create a legal rule to allow works like those of Randall and Colting to survive claims of infringement. In particular, with the ALRC now considering adding both transformative uses and fair use into Australian copyright $\operatorname{law}^{23}$ it is pertinent to examine the legal issues surrounding SunTrust and Salinger $v$ Colting. It might well be that where satirical or parodic novels are concerned, fair use is the least unattractive option. While it might not deliver the certainty that stakeholders desire, it does have the potential to provide a free use space for parodies. ${ }^{24}$ If the ALRC does recommend that Australian copyright law imports fair use into the Copyright Act then the American jurisprudence will be more relevant than ever before in determining the scope and shape of Australia's copyright exceptions.

At the outset of this paper it should be acknowledged that there are other dimensions to the policy problem of accommodating literary re-writes. First, these works are derivative works and the question of compensation for the original author is a legitimate consideration. ${ }^{25}$ There is a colourable argument that at the very least they should not be subjected to a legal regime that is so binary that it offers only the choice of infringement and suppression or complete freedom from copyright infringement. However, it is beyond the scope of this paper to consider questions of compulsory licensing and alternative compensation schemes. Secondly, this paper will not explore the boundaries of ss $41 \mathrm{~A}$ and 103AA of the Copyright Act. In terms of black letter law this paper will confine itself to fair use.

\section{An ARgument For SATIRE}

Legal policy is a complex art, ${ }^{26}$ and policy development in copyright law is peculiarly so. The legislature must contend not just with different stakeholders, but with new problems created by new technologies and international legal

\footnotetext{
${ }^{23}$ ALRC, above n 1, 36-40, 71-9.

${ }^{24}$ There are some interesting legal issues that will arise here should Australia import fair use. As noted above, the Supreme Court in Campbell, 510 US 569 (1994) distinguished between parody and satire. The Court held that parody could be protected under fair use whereas satire could not. This would need to be reconciled with Australia's fair dealing provisions which refer to parody or satire as potential fair dealings.

${ }^{25}$ For example, an attempt to 're-write' Nabakov's Lolita from the perspective of the ill-fated heroine resulted in a copyright suit which was resolved by a settlement between the original author's estate and the second author. See Michiko Kakutani, “Lo’s Diary”: Humbert Would Swear this isn't the Same Lolita', New York Times (New York), 29 October 1999 $<$ http://www.nytimes.com/books/99/10/24/daily/102999pera-book-review.html>.

${ }^{26}$ Louis Mayo and Ernest Jones, 'Legal Policy Decision Process: Alternative Thinking and the Predictive Function’ (1965) 33 George Washington Law Review 318.
} 
rules. ${ }^{27}$ It requires the balancing of competing principles and priorities. This is not a task that can easily be managed. Often two or more principles will stand in conflict with each other. This conflict can emerge from the different perspectives and aspirations of different stakeholders in a given area of policy. It might arise from the legal subject matter itself, wherein long-established legal rules may clash with emerging legal norms. Some form of resolution will be required before any legal policy idea can properly be developed and advanced.

There can be little doubt that copyright law has been an area of deep contention over the past two decades. ${ }^{28}$ From peer-to-peer infringement, anticircumvention laws, copyright duration and enforcement matters, copyright law has been a fertile ground for debate. ${ }^{29}$ This is no less the case where free speech, satire, author's rights and fair dealing are concerned. ${ }^{30}$ There are a number of competing ideas that clamour for attention on this topic. It is helpful to unpack these ideas and to develop a basic policy idea that can underpin the forthcoming analysis of fair use and fair dealing.

The logical starting point in any analysis of copyright law and policy is theory. What follows here is a potted version of the theoretical debates that have accompanied recent policy debates over copyright law. The point that I am driving at below is that (1) if copyright is a statutory monopoly conceived and proffered on a utilitarian basis (2) within a liberal democracy in which free speech is a quixotic if not an essential element in maintaining the health of that democracy, then the former should accede to the latter whenever the two come greatly into conflict. That is not to say that free speech should override copyright at all times. Were that to happen then free speech would 'gut'

${ }^{27}$ As Gleeson CJ, Hayne, Gummow and Heydon JJ noted in Stevens v Kabushiki Kaisha Sony Computer Entertainment (2005) 221 ALR 448, 449 [1]: 'Over a long period amendments to copyright law have comprised legislative solutions to problems created by competing economic and social pressures associated with the development of new technologies.'

${ }^{28}$ See Jane Ginsburg, 'How Copyright Got a Bad Name for Itself' (2002) 26(1) Columbia Journal of Law \& the Arts 61. See also Lawrence Lessig, The Future of Ideas: The Fate of the Commons in a Connected World (Random House, 2001); Siva Vaidhyanathan, Copyrights and Copywrongs: The Rise of Intellectual Property and how it Threatens Creativity (New York University Press, 2001); Neil Weinstock Netanel, Copyright's Paradox (Oxford University Press, 2008).

${ }^{29}$ Ginsburg, above n 28.

30 See John Newman, 'Holden Caulfield Grows Up: Salinger v Colting, the Promotion-ofProgress Requirement, and Market Failure in a Derivative-Works Regime' (2011) 96 Iowa Law Review 737; Anthony Reese, 'Transformativeness and the Derivative Work Right' (2008) 31 Columbia Journal of Law and Arts 467; Rebecca Tushnet, 'User-Generated Discontent: Transformation in Practice' (2008) 31 Columbia Journal of Law and Arts 497; Brigitte Gladis, 'District Courts, Fair Use, and Literary Parodies: Parsing the Beautiful, Reciprocal Arrangement' (2011) 41 Seton Hall Law Review 1169. 
copyright. $^{31}$ Instead, there must be particular defined contexts wherein free speech values are privileged over copyright. Arguably, the literary 're-write' or 'writing back' is just such a context. If that point is accepted then the question that arises is whether the legal rules that are currently in place appropriately serve the primacy of free speech, as embodied by the parodic or satirical novel, over copyright protection.

To begin with, natural rights theory is closely entwined with copyright law. ${ }^{32}$ From a natural rights perspective a work that may be protected by copyright embodies the personality of the author. As Diderot stated, '[w]hat form of wealth could belong to a man, if not the work of the mind ... the most precious part of himself, that will never perish, that will immortalize him'. ${ }^{33}$ This theory also supports a moral entitlement to property rights in creative work owing to the efforts of the author. There is an obvious overlap between Locke's labour theory, a protean concept in copyright law, and natural rights in general. ${ }^{34}$ The protection of copyright becomes then a matter of protecting the author's self. This notion of natural rights finds immediate application in the structure of copyright laws. Notwithstanding the question of joint authors, the rights that accrue to the copyright owner are expressed as individual rights. The copyright owner immediately acquires these rights - such as the rights to copy, communicate and adapt a work — as soon as the work is created. The most obvious expression of natural rights theory in copyright laws are moral rights. ${ }^{35}$ These encompass the right to artistic integrity, attribution, and the right not to have authorship falsely attributed.

However, natural rights theory neither fully explains nor powers the existence of copyright law. As the laws of duration now vaguely attest, copyright is a temporary monopoly. The notion of natural rights must yield to the utilitarian bargain theory of copyright. As Leval notes, 'copyright is not an inevitable, divine or natural right that confers on authors the absolute ownership of their

${ }^{31}$ See Note, 'Gone With the Wind Done Gone: “Re-Writing” and Fair Use' (2002) 115 Harvard Law Review 1193, 1214.

${ }^{32}$ Locke's labour theory, which is frequently pressed into service in copyright debates, has a strong connection to natural rights. See Carys Craig, 'Locke, Labour and Limiting the Author's Right: A Warning against a Lockean Approach to Copyright Law' (2002) 28 Queen's Law Journal 1; John Locke, Two Treatises of Government (Awnsham Churchill, 1690).

33 Denis Diderot, 'Lettre historique et politique adressée à un magistrat sur le commerce de la librairie’ (1763) in Roger Lewinter (ed), Oeuvres complètes (Club Français du Livre, 1970) vol 5331.

${ }^{34}$ Craig, above n 32. See discussion below nn 39-41.

${ }^{35}$ Moral rights has already proven to be a roadblock for remix culture. See Perez $v$ Fernandez [2012] FMCA 2. 
creations. It is designed rather to stimulate activity and progress in the arts for the intellectual enrichment of the public'. ${ }^{36}$

This begs the questions of why such a monopoly may be temporarily granted and whether the monopoly is to be complete and uncontested. The answer again lies in the architecture of copyright laws, but also in the founding statutes and constitutional clauses that have given rise to modern copyright law.

As has been well-explained elsewhere, the Statute of Anne 1710 was the first copyright statute. ${ }^{37}$ The Statute of Anne introduced the concepts of the author as copyright owner and of a fixed term of protection for copyright works. In its own chapeau the Statute illustrates its purpose as being 'an act for the encouragement of learning, by vesting the copies of printed books in the authors or purchasers of such copies, during the times therein mentioned'. Similarly, the Copyright Clause of the Constitution of the United States provides that Congress shall have the power 'to promote the progress of science and useful arts, by securing for limited times to authors and inventors the exclusive right to their respective writings and discoveries'. ${ }^{38}$ While the United States Copyright Clause is not reflected in the bare grant of power that sits in the Australian Constitution there is an undoubted consonance between the two constitutions and, in the main, the national approaches to copyright law.

More pertinently there is a strong utilitarian bent that runs through copyright law. Some concept of the social good, no matter that it is poorly defined or inadequately expressed, forms part of the rationale for providing copyright protection in the first place. In this sense copyright is a reciprocal bargain between the author and the public. ${ }^{39}$ While there have been attempts by copyright stakeholders to recast the bargain as simply a vesting of private property rights in copyright owners, ${ }^{40}$ the courts in both the United States and

\footnotetext{
${ }^{36}$ Pierre Leval, 'Toward a Fair Use Standard' (1990) 103 Harvard Law Review 1105, 1107. See Harper \& Row, 471 US 539, 545-6 (1985).

${ }^{37}$ Dianne Zimmerman, 'The Statute of Anne and its Progeny: Variations Without a Theme' (2010) 47 Houston Law Review 965. See also Lyman Ray Patterson, Copyright in Historical Perspective (Vanderbilt University Press, 1968); Lyman Patterson, 'The Statute of Anne: Copyright Misconstrued' (1966) 3 Harvard Journal on Legislation 223.

${ }^{38}$ United States Constitution art 1 \& $8 \mathrm{cl} 8$.

${ }^{39}$ See Fogerty v Fantasy Inc, 510 US 517, 526 (1994) ('Fogerty'); Sony Corporation of America $v$ Universal City Studios, Inc, 464 US 417, 429 (1984) ('Sony'). In Fogerty, the Supreme Court, citing Sony, stated at 526: 'We have often recognized the monopoly privileges that Congress has authorized, while "intended to motivate the creative activity of authors and inventors by the provision of a special reward," are limited in nature and must ultimately serve the public good.'

${ }^{40}$ This has often taken the form of using the rhetoric of 'theft' or 'piracy'. See Neil Netanel, 'Why has Copyright Expanded? Analysis and Critique' in Fiona Macmillan (ed), New Directions in Copyright Law (Edward Elgar, 2008) vol 6, 3, 11-2.
} 
Australia have been resolute in pointing out that protection is offered in exchange for the production of creative works. ${ }^{41}$ This bargain is best expressed by Reed J in Mazer $v$ Stein: ${ }^{42}$

The economic philosophy behind the clause empowering Congress to grant patents and copyrights is the conviction that encouragement of individual effort by personal gain is the best way to advance public welfare through the talents of authors and inventors in 'Science and useful Arts. Sacrificial days devoted to such creative activities deserve rewards commensurate with the services rendered.

This comment speaks to both the utilitarian and labour theories of copyright law. Put simply, the best way to maximise society's welfare is to encourage and reward authors for producing creative works. ${ }^{43}$ The flaw in this theory, which Lessig identifies in his text on Remix culture, is that it pre-supposes a clear divide between the creative classes and the non-creative classes. ${ }^{44}$ Presumably, the former are the entitled owners of copyright and the latter are the noncreative consumers of copyright works.

Lessig argues that this divide is untenable. Indeed, the emergence of remix culture has amply illustrated that the barrier between the creative classes and the audience is not so much sheer as infinitely permeable. ${ }^{45}$ There is quite evidently a whole new genre of user-generated content that has sprung up around sites such as YouTube, Flickr, MySpace and Facebook.

The emergence of the culture of user-generated content places pressure upon the utilitarian ideal in copyright law. If utilitarianism supports the limited protection of copyright so as to maximise the production of creative works, why should

\footnotetext{
${ }^{41}$ See the Supreme Court’s decisions in Fogerty, 510 US 517, 526 (1994) and Sony, 464 US 417, 429 (1984). In Australia, the High Court has stated in IceTV Pty Ltd v Nine Network Australia (2009) 239 CLR 458, 464 ('IceTV'): 'Copyright legislation strikes a balance of competing interests and competing policy considerations. Relevantly, it is concerned with rewarding authors of original literary works with commercial benefits having regard to the fact that literary works in turn benefit the reading public.'

42347 US 201, 219 (1954) (Reed J).

${ }^{43}$ See William Fisher, 'Theories of Intellectual Property’ in Stephen R Munzer (ed), New Essays in the Legal and Political Theory of Property (Cambridge University Press, 2001) 168 $<$ http://cyber.law.harvard.edu/people/tfisher/iptheory.pdf>. See also William Landes and Richard Posner, ‘An Economic Analysis of Copyright Law' (1989) 18 Journal of Legal Studies 325.

${ }^{44}$ Lawrence Lessig, Remix: Making Art and Commerce Thrive in the Hybrid Economy (Penguin Press, 2008).

${ }^{45}$ See Daniel Gervais, 'The Tangled Web of UGC: Making Copyright Sense of User-Generated Content' (2009) 11(4) Vanderbilt Journal of Entertainment and Technology Law 841. Also, Anupam Chander and Madhavi Sunder, 'Everyone's a Superhero: A Cultural Theory of "Mary Sue” Fan Fiction as Fair Use’ (2007) 95 California Law Review 597.
} 
copyright protection be near maximalist when less protection will produce more works and encourage higher levels of access? The rationale underpinning the bargain has begun to fade. To persevere with strong copyright laws seems tenable then if one accepts the labour theory as providing a strong basis for protection. Yet, while Locke's labour theory has never met with sustained opposition, there has been a judicial retreat from the labour theory as the basis for copyright. In Feist $v$ Rural $^{46}$ the Supreme Court of the United States abandoned the labour theory of copyright by rejecting the sweat of the brow doctrine. Similarly, in the IceTV case, the High Court of Australia gave tepid support, if that, to the labour theory. ${ }^{47}$

What we now lack is a theory that supports strong copyright protection in a society where users generate content themselves. The theories that have developed over centuries, often at times where writers were part of a privileged or well patronised class, are now less applicable in a more democratic sphere. Both the natural rights theory and even Locke's labour theory lack a firm basis in modern copyright law. Moreover, while it is clear that utilitarianism supports copyright protection it does so on the basis that protection results in more creative works. Yet, technology has inverted this paradigm. As SunTrust indicates, copyright protection may lead to less creative works. That is, if SunTrust had succeeded in its claim against Houghton Mifflin, Randall's novel would not have been published. Further, SunTrust used its copyright rights to serve as the legal muscle behind the licensing of derivative rights to authors who would write a sequel to GWTW. This led to the rather unsavoury request, recounted before the $11^{\text {th }}$ Circuit in SunTrust that a potential author not write a sequel that included 'miscegenation' and homosexuality. ${ }^{48}$ The author who would have written the sequel regarded the request as repugnant. No further creative work was forthcoming in that instance.

Having stated the basic inquiry of this essay in the Introduction it is helpful to revisit it at this point. In effect, some novels, which broadly be characterised as parodic or satirical, must copy substantial parts of other works in order to make their particular point. The existence of these novels, or even shorter pieces of work, is likely to be more prevalent in an environment where getting published is significantly easier. These works represent a substantial addition to the

\footnotetext{
${ }^{46}$ Feist Publications Inc v Rural Telephone Service Co, 499 US 340 (1991). The Supreme Court's rejection of the sweat of the brow doctrine was based on the view that the doctrine flouted established rules of copyright by supporting proprietary rights for non-copyrightable materials such as facts.

${ }^{47}$ IceTV (2009) 239 CLR 458.

${ }^{48}$ I take it as self-evident that the use of the dated term 'miscegenation' is in itself repugnant. The aversion to homosexuality should warrant similar censure. Nonetheless, copyright law is not concerned with prejudices or philosophies of copyright owners.
} 
common stock of culture, but they also represent a challenge to the original author's economic and artistic interests. Herein lies the problem: as a society we are well served by an expanding and dynamic literary and artistic culture but the legal architecture within which this culture has thrived has firmly entrenched rules of copyright law which strongly favour original authors over derivative creators. $^{49}$

We might be well served then to step away from the theoretical and doctrinal concerns of copyright law and to examine our nascent policy problem from a different perspective. It is useful to consider the question of the literary re-write from within the context of free speech and self-expression. Indeed, while the literary re-write might be an issue of copyright infringement, it is also an issue of freedom of expression. In particular, it is well worth making the point that the type of copyright infringement that we are dealing with here is not simple plagiarism or an attempt to take a work without having to pay for it. The plagiarist or the surreptitious copier seeks to hide their copying for personal gain or profit. As Posner, writing in the context of plagiarism, has noted:

Concealment is at the heart of plagiarism. But it must be carefully defined. It is not a mere failure to acknowledge copying. Often copying is not acknowledged because it is known to the intended readership. A parody may quote extensively from the work parodied, and always it will copy distinctive features of style and theme, yet often without mentioning the parodied work. But the parodist will plant clues so numerous and unmistakeable that the reader will recognise the copying, for otherwise the parody will not be recognised as a parody and the parodist's intentions will be thwarted. ${ }^{50}$

Plagiarism and parody stand in an obvious contradistinction to each other. Posner begins his short book on plagiarism by recounting the story of Kaavya Viswanathan who wrote the novel How Opal Mehta Got Kissed, Got Wild, and Got a Life while still a teenager and a sophomore at Harvard. Perhaps owing to her youth and alma mater, the subsequent plagiarism scandal attracted excessive notoriety. In Opal Mehta, Viswanathan had plagiarised passages from several authors, including Megan McCafferty, who was a competing author in the market for teen fiction and from whom a substantial number of passages were taken. Whether the plagiarism was intentional or the product of a photographic memory, ${ }^{51}$ the copying had the effect of using the original author's work to outcompete her in the same market. ${ }^{52}$ While I am mindful of the difference

\footnotetext{
${ }^{49}$ Netanel, above, n 14 argues that copyright serves established interests of large stakeholders over smaller players.

${ }^{50}$ Richard Posner, The Little Book of Plagiarism (Knopf Doubleday, 2007) 17-18.

${ }^{51}$ Ibid 5.

52 Posner noted that Viswanathan's changes improved on McCafferty's prose, but in doing so 'used her own words against her' in the 'chick-lit' market: Ibid 70.
} 
between plagiarism and copyright, the use of one author's work to capture their market strikes at the heart of copyright law.

Yet, parody is fundamentally different. As the Supreme Court noted in Campbell $^{53}$ a parody might suppress demand for the original via a withering critique, but this is a different thing to coveting the original's market through mimicry. The parodic or satirical novel involves copying that makes a social or political point or argument. In other words, the satirical novel is a speech act. The protection of this type of novel demonstrates how greatly we value free speech.

This was a live issue during the SunTrust litigation. In the United States the First Amendment explicitly protects freedom of expression. The $11^{\text {th }}$ Circuit acknowledged that copyright could be used to limit free speech and found that it was inappropriate in the SunTrust case. When this issue had arisen previously in American jurisprudence, courts had expressed the view that copyright's internal safety valves, such as fair use and the idea/expression dichotomy ensured copyright's consistency with the First Amendment. These obiter remarks in Harper \& Row drew upon the famous paper on copyright and the First Amendment by Melville Nimmer. ${ }^{54}$ In that paper Nimmer argued that the internal requirements of copyright law protected it from First Amendment scrutiny by providing sufficient safety valves for free expression. However, Netanal pointed out that Nimmer's appraisal of the relationship between copyright and the First Amendment was written well before the lengthy extension of duration, the rise of 'para-copyrights', and the general strengthening of copyright law. ${ }^{55}$ Accordingly, at least in the United States, constitutional issues might be relevant in cases where parodic novels are disputed.

The extent to which the values of free speech find application in the doctrines and statutes of Australian law is a matter of some debate. The most famous embodiment of free speech values is the implied freedom of political communication. $^{56}$ Yet, this is a constitutional doctrine whose limits are increasingly more apparent and are tied to ss 7 and 24 of the Constitution. ${ }^{57}$

${ }^{53}$ Campbell, 510 US 569, 590-1 (1994).

${ }^{54}$ Nimmer, above n 16.

${ }^{55}$ Netanel, above n 14.

${ }^{56}$ See Theophanous $v$ Herald \& Weekly Times Ltd (1994) 182 CLR 104; Nationwide News Pty Ltd $v$ Wills (1992) 177 CLR 1; Australian Capital Television v Commonwealth (1992) 177 CLR 106.

${ }^{57}$ Australian Constitution ss 7, 24. See Lange v Australian Broadcasting Corporation (1997) 189 CLR 520, 567 ('Lange') where the High Court stated '... two questions must be answered before the validity of the law can be determined. First, does the law effectively burden freedom of communication about government or political matters either in its terms, operation or effect? 
There are limits to free speech in the form of the racial hatred provisions of the Racial Discrimination Act 1975 (Cth) and the inciting violence provisions of the Criminal Code. ${ }^{58}$ It is notable that a clear relationship between free speech and the proscription of racial hatred exists in pt IIA of the Racial Discrimination Act. ${ }^{59}$ That is, ss $18 \mathrm{C}$ and 18D set out a test of proportionality for balancing one against the other. Similarly, in Lange ${ }^{60}$ and other cases, the High Court has developed and refined a test of proportionality for balancing the restraint on legislative power contained in the implied freedom of communication against the desired policy goal of the legislature. In both instances the proportionality test involving free speech and some other legislative end is clearly set out.

What is lacking in the Copyright Act is any clear legal rule that imposes free speech on Australian copyright law. Australia lacks the First Amendment which the United States enjoys. There is no great Antipodean counterpoint on a constitutional level to the restriction on speech presented by copyright law. The implied freedom only has operation with respect of legislative action, but it does not apply against private actors. ${ }^{61}$ Moreover, in the one case where free speech values were arguably considered in Australian copyright law, Commonwealth $v$ John Fairfax \& Sons, ${ }^{62}$ the question of free speech was not explicitly addressed. Nonetheless, the John Fairfax case, which involved an argument of fair dealing with regard to the unauthorised publication of government documents, does

Second, if the law effectively burdens that freedom, is the law reasonably appropriate and adapted to serve a legitimate end the fulfilment of which is compatible with the maintenance of the constitutionally prescribed system of representative and responsible government.'

${ }^{58}$ Criminal Code Act 1995 (Cth) sch 1 s 11.4 .

${ }^{59}$ See Toben $v$ Jones (2003) 199 ALR 1; Jones v Scully (2002) 120 FCR 243; Eatock v Bolt [2011] FCA 1103 ('Bolt'). In Bolt, Bromberg J, commenting on pt IIA of the Racial Discrimination Act and racial vilification, stated at [6]: 'Section 18D exempts from being unlawful, conduct which has been done reasonably and in good faith for particular specified purposes, including the making of a fair comment in a newspaper. It is a provision which, broadly speaking, seeks to balance the objectives of s $18 \mathrm{C}$ with the need to protect justifiable freedom of expression.'

${ }^{60}$ (1997) 189 CLR 520.

61 Melissa De Zwart, 'The Future of Fair Dealing in Australia: Protecting Freedom of Communication' (2007) 4(1) Script-Ed 96, 110.

62 (1980) 147 CLR 39 ('John Fairfax'). In this case, two former employees of the Department of Foreign Affairs and Trade attempted to publish a book about East Timor. The book contained departmental documents which were produced without authorisation. The case was primarily a breach of confidence matter, but copyright defences relating to fair dealing and the public interest defence were raised. The Commonwealth succeeded in its copyright claim. In his major work on free speech, Chesterman has argued that John Fairfax was a copyright case that recognised free speech even though this was not explicitly stated. See Michael Chesterman, Freedom of Speech in Australia: A Delicate Plant (Ashgate, 2000) 7. 
suggest that fair dealing plays a similar role in protecting free speech values under Australian law as it does under American law. ${ }^{63}$ Mason J stated:

However, there is another possible approach to the concept of 'fair dealing' as applied to copyright in government documents, an approach which was not spelled out in argument by the defendants. It is to say that a dealing with unpublished works which would be unfair as against an author who is a private individual may nevertheless be considered fair as against a government merely because that dealing promotes public knowledge and public discussion of government action. This would be to adopt a new approach to the construction of ss 41 and 42 and it would not be appropriate for me on an interlocutory application to proceed on the footing that it is a construction that will ultimately prevail. Situations such as the present case would scarcely have been within the contemplation of the draftsman when the two sections and their ancestors were introduced. ${ }^{64}$

It is perhaps quite helpful that in legal policy we are not confined by the rigid application of doctrinal rules, one between the other, as we would be in the realm of black letter law. Moreover, what Netanel's analysis proves is that the harmony that might once have existed between the values of free speech and the rules of copyright law has been disturbed by the expansion of the latter. ${ }^{65}$ This does not need to be addressed purely as a doctrinal or constitutional matter. Though there is little jurisprudence in Australia regarding the tensions between free speech and copyright law there is a general acceptance of free speech as an important part of a liberal democracy. This has been expressed politically and judicially. Further, it stands to reason that in a liberal democratic state such as Australia, copyright must have some relationship to free speech. Why else then would there be fair dealing exceptions for reporting the news, criticism and review and now parody or satire? These internal requirements would operate in a similar way that fair use is meant to operate in the United States in maintaining a balance with free speech. There is scope for considering how the values of free speech can inform the future development of Australian copyright law.

There are three justifications put forward for free speech: the search for truth, autonomy and democracy. The basis for the search for the truth argument is that if speech is truly free then the truth can be discovered in an unrestrained discourse. Similarly, the autonomy argument ties free speech to personal

${ }^{63}$ De Zwart has traced the development of the fair dealing laws and has identified that at their genesis some judicial consideration was given to freedom of expression. See Melissa De Zwart, 'A Historical Analysis of the Birth of Fair Dealing and Fair Use: Lessons for the Digital Age' (2007) 1 Intellectual Property Quarterly 60, 63.

${ }^{64}$ John Fairfax (1980) 147 CLR 39, 50 [45].

${ }^{65}$ Netanel, above $n 14$. 
liberty. ${ }^{66}$ A free human being should have the autonomy to express themselves as they choose. In this sense, freedom of expression is tied to personhood and autonomy. The democracy argument in free speech is best illustrated by Oliver Wendell Holmes' concept of the marketplace of ideas. ${ }^{67}$ Holmes' argument is that free speech allows an idea to get itself accepted in a market filled with competing ideas.

These arguments in favour of free speech have immediate application in the context of Randall and Colting's novels. It is undeniably clear that there is a broader political purpose behind Randall's novel. TWDG challenges the sanitised view of slavery presented by Mitchell's GWTW. In this sense TWDG is a literary embodiment of the search for the truth. It is a riposte to the falsehood that might be said to exist in Mitchell's novel. Moreover, in order to expose that falsehood, and to locate it perfectly in Mitchell's novel, Randall had to take a substantial part of the original novel.

Given that free speech is often tightly linked to political matters and the functioning of democracy, Randall's novel, which deals with the hot button issue of race, is easier to tie in with the arguments in favour of free speech. The task is somewhat more difficult with respect to Colting's 60YL. There is no underlying 'political' message in 60YL; rather, the novel is an examination of the author's relationship with a character that he created.

Whether that should deny Colting protection under the banner of free speech is less clear. On a theoretical level there is no great stipulation that only political speech should be free and that any other type of speech is less deserving of protection. Yet, on a doctrinal level, First Amendment jurisprudence is replete with instances of fulsome protection being given to political speech, no matter how objectionable, whereas less protection is given to commercial speech. Despite its commercial nature, 60YL might be regarded as an example of artistic expression, albeit one that draws heavily on a pre-existing source.

From the foregoing discussion, four useful propositions can be developed. First, the theoretical basis that underpins copyright protection is largely that of utilitarianism. At its heart this theory supports copyright protection in pursuit of the greater good in terms of the maximising the production of creative works. Secondly, the utilitarian basis of copyright protection is now faltering in the remix era as users have proved themselves incredibly adept at creating derivative works. These works are well and truly a step beyond mere plagiarism and they represent genuine derivative creativity. Thirdly, satire is a part of this derivative creativity and a part of free speech. Fourthly, free speech and

\footnotetext{
${ }^{66}$ See Lee Bollinger, 'Free Speech and Intellectual Values' (1983) 92 Yale Law Journal 438.

${ }^{67}$ Abrahams v United States, 250 US 616, 630 (1919).
} 
copyright law need a relationship wherein one can be weighed and balanced against the other as circumstances require. In other contexts the proportionality test that pits free speech against countervailing considerations, such as restrictions on harmful racist speech, is more clearly articulated. However, copyright has never denied a relationship to free speech. The problem has been that the relationship has never really been clearly addressed and articulated.

Weighing these propositions together seems to lead to the inevitable conclusion that a rule must be created. However, such a conclusion might be premature. The next step is to consider whether the existing rule that sits in place within copyright law, namely, fair use, adequately serves the task of balancing free speech against copyright protection. If so, might it perform that task better than Australia's current fair dealing exceptions?

\section{THE LIMITS OF FAIR USE?}

Fair use can hardly be regarded as a doctrine with certain and defined boundaries. In Dellar $v$ Samuel Goldwyn Inc, ${ }^{68}$ the $2^{\text {nd }}$ Circuit referred to the doctrine as 'the most troublesome in the whole law of copyright' ${ }^{69}$ Lessig has referred to fair use as 'the right to hire a lawyer' ${ }^{70}$ Numerous scholars and courts have criticised the seemingly enigmatic doctrine. ${ }^{71}$ There are good reasons for these criticisms. It was by no means clear that the Supreme Court would adopt Judge Leval's proposal that fair use should embrace transformative use. ${ }^{72}$ Yet, it did so in the seminal case of Campbell and in doing so set the basis for parody and transformative use to become organising principles within fair use jurisprudence. In Campbell, the rap band 2-Live Crew had copied and parodied Roy Orbison's song Oh, Pretty Woman. Where Orbison's lyrics had been naïve and romantic, 2-Live Crew's lyrics contained base humour and crudeness.

\footnotetext{
${ }^{68} 104$ F 2d 661 (2 ${ }^{\text {nd }}$ Cir, 1939) ('Dellar').

${ }^{69}$ Ibid 662.

${ }^{70}$ Lawrence Lessig, Free Culture: How Big Media Uses Technology and the Law to Lock Down Culture and Control Creativity (Penguin Books, 2004) 187.

${ }^{71}$ See William Fisher III, 'Reconstructing the Fair Use Doctrine' (1988) 101 Harvard Law Review 1659; Gordon, above n 14; Leval, above n 36; Jessica Litman, 'Billowing White Goo' (2008) 31 Columbia Journal of Law and Arts 587. See also Princeton University Press $v$ Michigan Document Services Inc, 99 F 3d 1381, 1392 (6 ${ }^{\text {th }}$ Cir, 1996) where Nelson J stated: 'Fair use is one of the most unsettled areas of the law. The doctrine has been said to be 'so flexible as virtually to defy definition"'.

${ }^{72}$ See Leval, above $n 36$.
} 
There are four factors to be considered in any fair use analysis. Section 107 of the United States Copyright Act provides that a use of a copyright protected work may be a fair use depending upon:

(1) the purpose and character of the use, including whether such use is of a commercial nature or is for nonprofit educational purposes;

(2) the nature of the copyrighted work;

(3) the amount and substantiality of the portion used in relation to the copyrighted work as a whole; and

(4) the effect of the use upon the potential market for or value of the copyrighted work.

The four-factor test must be applied on a case by case basis and no 'bright line' rule exists for determining whether an impugned use is a fair use. ${ }^{73}$ The purpose of fair use is in fact to allow a flexible approach to deciding whether a free use exception applies. In enacting $\S 107$ of the Copyright Act, Congress had merely sought to restate the judicially created doctrine of fair use rather than to alter it. Fundamentally, the inquiry is concerned with whether the use of the original copyright protected work is fair. As Leval has noted, despite oft-repeated references to fair use as an equitable rule of reason, the doctrine has no basis in equity and is instead a creature of the courts of the common law. ${ }^{74}$ Accordingly, the motives of the secondary user are generally of less relevance and it is the characterisation of the overall use as fair or unfair that is of paramount concern. In principle, each of the four factors is to be given weight. In practice, two factors, the first, which deals with the purpose and character of the use, and the fourth, which concerns the effect on the market for the original work, have emerged as the two leading considerations in fair use cases. ${ }^{75}$

The first and fourth factors embody two different approaches to fair use. The first factor sets the basis for the transformative use approach to fair use. The fourth factor underpins the market failure approach to fair use.

In Campbell, the Supreme Court identified the primary enquiry under the first factor as being whether the second work merely superseded the original or whether it added something new. Justice Souter, delivering the opinion of the Court, explicitly endorsed Leval's treatment of transformative works. Further,

\footnotetext{
${ }^{73}$ Campbell, 510 US 569, 577 (1994).

${ }^{74}$ Leval, above n 36, 1127.

${ }^{75}$ Barton Beebe, 'An Empirical Study of US Copyright Fair Use Opinions, 1978-2005' (2008) 156 University of Philadelphia Law Review 549, 582-6. See also Neil Netanel, 'Making Sense of Fair Use' (2011) 15(3) Lewis \& Clark Law Review 715.
} 
Souter $\mathrm{J}$ held that 'the more transformative the new work, the less will be the significance of other factors, like commercialism' ${ }^{76}$ His Honour also noted that parody had 'an obvious claim to transformative value'. ${ }^{77}$

Souter J noted with regard to the second factor that creative works were closer to the core of copyright. However, he held that this was of little assistance in parody cases given the need for parodies to copy heavily from the original work. Souter J stated that the creative nature of the original work did not 'help much in separating the fair use sheep from the infringing goats in a parody case, since parodies almost invariably copy publicly known, expressive works' ${ }^{78}$ In relation to the third factor the Court recognised the need for the parody to conjure up the original. Souter J stated:

Parody's humor, or in any event its comment, necessarily springs from recognizable allusion to its object through distorted imitation. Its art lies in the tension between a known original and its parodic twin. When parody takes aim at a particular original work, the parody must be able to 'conjure up' at least enough of that original to make the object of its critical wit recognizable. $^{79}$

The Supreme Court did not define the scope of the test for 'conjuring up' the original work. The Court noted that it was appropriate for a parody to take the heart of the original so as to conjure up the earlier work. ${ }^{80}$ However, the Supreme Court remanded to the Court of Appeal the question of whether 2-Live Crew had taken an excessive amount of the original. ${ }^{81}$ With regard to the fourth factor the Supreme Court held that the commerciality of the parody did not necessarily entail a finding of market harm. ${ }^{82}$ Moreover, while the parody might harm the market for the original through its critique, that will not amount to unfair use because it does not equate to supplanting the original in its own market through substitution. ${ }^{83}$ The Court stated 'there is no protectable derivative market for criticism. The market for potential derivative uses includes only those that creators of original works would in general develop or license others to develop' ${ }^{84}$

\footnotetext{
${ }^{76}$ Campbell, 510 US 569, 579 (1994).

${ }^{77}$ Ibid.

${ }^{78}$ Ibid 586.

${ }^{79}$ Ibid 588.

${ }^{80}$ Ibid.

${ }^{81}$ Ibid 589.

${ }^{82}$ Ibid 591.

${ }^{83}$ Ibid 591-2.

${ }^{84}$ Ibid.
} 
The significance of Campbell is hard to overstate. In deciding that 2-Live Crew's use of Orbison's song was fair use because it was both transformative and a parody, the Supreme Court steered fair use away from the market failure theory of fair use and into waters that favoured a broader approach to free speech. In this sense, Campbell was the counterpoint to the Supreme Court's decision in Sony. Where Sony had favoured fair use on the basis that timeshifting was not competing with the market, thereby buying in to the market failure theory of fair use, the primacy of parody and transformative use in Campbell ${ }^{85}$ recognised the need for writers to use the works of other writers in order to make particular points.

It seems easy to conclude that fair use jurisprudence in the United States swapped one set of organising principles, market failure, for another set, parody and transformative use, in the 1990s. To some extent this is true. After the Campbell decision there were a number of cases that tried to call on transformative use in order to evade copyright infringement claims. Yet, at the same time there were cases that tried to call on the market failure theory, mainly as the defendants pedalled infringing products that targeted a gap in the market. ${ }^{86}$

The better picture of the situation is that fair use's voluminous jurisprudence comprises clusters of which the parody cases are but one such cluster. ${ }^{87}$ Overlaying the clusters are the two different theoretical approaches to fair use: transformative use and market failure. They are quite different, but are not diametrically opposed to each other. For example, the transformative use approach to fair use which supports parody can also call upon market failure because there is often no market for licences from the owner of an original copyright work for parodies of their work.

Samuelson has studied fair use cases and has proffered five different clusters of cases based upon use: (1) 'free speech and expression fair uses'; (2) 'authorship promoting fair uses'; (3) 'uses that promote learning'; (4) 'foreseeable uses of copyright' other than those stated in the chapeau of $\S 107$ (these include personal uses, litigation uses and government uses); and (5) 'unforeseen uses' (these broadly refer to new uses created by new technologies). ${ }^{88}$ Literary rewrites which might be fair uses can be located within this taxonomy of uses as free speech and expression fair uses.

\footnotetext{
${ }^{85}$ Campbell, 510 US 569, 579 (1994).

${ }^{86}$ See A\&M Records Inc v Napster Inc, 239 F 3d 1004 (9 $9^{\text {th }}$ Cir, 2001).

${ }^{87}$ See Beebe, above n 75; Samuelson, below n 88.

${ }^{88}$ Pamela Samuelson, 'Unbundling Fair Uses’ (2009) 77 Fordham Law Review 2537, 2544-6.
} 
In the cluster of cases that Samuelson identifies it is clear that fair use can promote the purposes of free speech. For example, in Nordstrom Inc $v$ $P A R A N,{ }^{89}$ fair use permitted the distribution of a store's advertisement in a leaflet with accompanying text pointing out why it was racist. In cases like Nordstrom, it was clear that copyright was being used to suppress speech that was critical of the copyright owner or which would reveal undesirable behaviours or facts. Samuelson put forward parodies as being examples of 'new works that criticize, comment upon, or offer new insights about ... the social significance of others' expressions'. ${ }^{90}$ In this sense the parody cases stand quite apart from the more blatantly political cases. In a slightly discordant note in an otherwise exceptional piece, Samuelson characterised SunTrust as an example of a 'nonparodic transformative critique' of an earlier work. ${ }^{91}$ However, it is clear from SunTrust that the $11^{\text {th }}$ Circuit regarded TWDG as a parody. The broader point that Samuelson makes is that parody is not the only form of transformative adaptation. Indeed, in Blanch $v$ Koons ${ }^{92}$ the use of an earlier work in a piece of transformative artistic expression was found to be fair use.

\section{A The Wind Done Gone as Fair Use}

Alice Randall's TWDG was published in 2001 by Houghton Mifflin. TWDG takes direct issue with the sympathetic treatment of slavery and Southern racism in Mitchell's GWTW. Where GWTW had effectively airbrushed the reality of slavery, TWDG exposed the inhumanity of slavery and the pervasiveness of racism in the South. TWDG begins by telling GWTW from the perspective of a slave called Cynara. In doing so, TWDG takes heavily from GWTW in order to re-tell the romance between Rhett and Scarlett and the reality of the South. That said, TWDG goes further than GWTW and contains parts that are clearly original.

Mitchell's estate argued that TWDG constituted an infringement of her copyright. Houghton Mifflin argued that TWDG was a fair use parody of GWTW. Mitchell's estate succeeded before the District Court and gained an injunction against the publication of Randall's novel. However, this was overturned by the $11^{\text {th }}$ Circuit. ${ }^{93}$

The similarities between TWDG and GWTW are extensive. Quite apart from the title, 'The Wind Done Gone' being a clever if obvious play on the original

\footnotetext{
${ }^{89}$ No 92-1349, 1992 US Dist LEXIS 9162 (DDC, 26 June 1992).

${ }^{90}$ Samuelson, above n 88, 2548-9.

${ }^{91}$ Samuelson, above $\mathrm{n} 88,2551$.

${ }^{92} 467 \mathrm{~F} 3 \mathrm{~d} 244$ ( $2^{\text {nd }}$ Cir, 2006).

${ }^{93}$ SunTrust, 268 F 3d 1257 (11 ${ }^{\text {th }}$ Cir, 2001).
} 
work, TWDG takes quite a lot from GWTW. There are similarities in the opening passages; GWTW begins: 'Scarlett O'Hara was not beautiful, but men seldom realized it when caught by her charm as the Tarleton twins were ...' whereas in TWDG Randall writes, 'She was not beautiful, but men seldom recognized this, caught up in the cloud of commotion and scent in which she moved. ${ }^{94}$ Similarly, TWDG takes characters, plot twists and settings from GWTW. However, the takings are not simply acts of blanket copying and a subversive purpose is evident in many instances. For example, Scarlett O'Hara becomes 'Other'; Rhett Butler becomes 'RB' or 'Debt Chaffeur'; Melanie becomes 'Mealy Mouth'; Tara becomes 'Tata' and Twelve Oaks Plantation becomes 'Twelve Slaves Strong As Trees'. ${ }^{95}$ Similarly, key scenes from GWTW are re-told from a slave's perspective. In fact, the slaves are portrayed as more intelligent than their vacuous white owners. In GWTW, Gerald wins Pork, his slave and butler, in a game of cards. In TWDG the scene is inverted so that Garlic (Pork) engineers the card game and the transfer from one owner to another. In TWDG, Cynara is the half-sister of Scarlett and she too marries Rhett Butler. ${ }^{96}$ However, TWDG is uniquely told from Cynara's perspective and continual dismissal of Scarlett as 'Other' mimics the 'othering' of minority races.

The District Court rejected Houghton Mifflin's fair use argument. Judge Pannell found that Randall's novel amounted to no more than a sequel to GWTW. ${ }^{97}$ Judge Pannell's approach to the issue of transformative use is rather puzzling. On the one hand he acknowledged that Randall adds new historical elements to GWTW by including the realities of slavery in TWDG. ${ }^{98}$ On the other hand, he characterised the re-write as simply being that the 'author takes Cynara on new adventures with the older work's characters' ${ }^{99}$ Judge Pannell never seemed to address how TWDG could be construed as transformative. Instead, he acknowledged that it contained some transformative elements, but that held that these elements were no greater than would be found in a sequel. ${ }^{100}$ Judge Pannell also found against TWDG on the second and third fair use factors. ${ }^{101}$ Having found TWDG to be little more than a sequel, Pannell J then found that it amounted to market substitution in relation to the fourth fair use factor. ${ }^{102}$

\footnotetext{
${ }^{94}$ SunTrust, 136 F Supp 2d 1357, 1369 (ND Ga, 2001).

${ }^{95}$ SunTrust, 268 F 3d 1257, 1267 (11 ${ }^{\text {th }}$ Cir, 2001).

${ }^{96}$ Ibid 1271.

${ }^{97}$ SunTrust, 136 F Supp 2d 1357, 1378 (ND Ga, 2001).

${ }^{98}$ Ibid 1375.

${ }^{99}$ Ibid.

${ }^{100}$ Ibid 1377.

${ }^{101}$ Ibid 1379-82.

102 Ibid 1382.
} 
The $11^{\text {th }}$ Circuit reversed the District Court's judgment. The $11^{\text {th }}$ Circuit found that TWDG constituted a fair use of GWTW. ${ }^{103}$ The Court identified the commerciality of the infringing work and its transformative nature as being the two most pertinent factors in relation to the first factor in the fair use test. However, the Court found that the transformative nature of TWDG greatly outweighed the commercial nature of the work. ${ }^{104}$ As the $11^{\text {th }}$ Circuit noted, '[a] work's transformative value is of special import in the realm of parody, since a parody's aim is, by nature, to transform an earlier work' ${ }^{105}$

Judge Birch, delivering the main opinion of the Court, identified the transformative nature of TWDG as arising from the unique and different perspective that it added to GWTW. ${ }^{106}$ Judge Birch noted that rather than being a mere work of fiction, TWDG constituted a critique and a rebuttal of GWTW in the guise of a work of fiction. ${ }^{107}$ Moreover, choosing to present her criticism in the form of a work of fiction arguably gave Randall a much wider audience than any academic commentary could ever have hoped to achieve. The Court noted the racism inherent in GWTW. Mitchell's narration and use of characters voiced racist sentiments. In GWTW, Scarlett states, 'The more I see of emancipation the more criminal I think it is. It's just ruined the darkies' ${ }^{108}$ Mitchell as narrator wrote of the African-Americans freed after the Reconstruction as being 'creatures of small intelligence ... [1]ike monkeys or small children turned loose among treasured objects whose value is beyond their comprehension, they ran wild - either from perverse pleasure in destruction or simply because of their ignorance'. ${ }^{109}$

In this context, Randall's use of characters and plotlines from GWTW was done in order to attack the racism of the original work. In TWDG, Randall makes 'Other', the literary counterpart to Scarlett, a person of mixed racial descent. Further, RB, Rhett's counterpart, leaves Other for Cynara. In turn, Cynara eventually inherits Tata (Tara in GWTW). Judge Birch noted:

While told from a different perspective, more critically, the story is transformed into a very different tale, albeit much more abbreviated. Cynara's very language is a departure from Mitchell's original prose; she acts as the voice of Randall's inversion of GWTW. She is the vehicle of parody; she is its means - not its end. It is clear within the first fifty pages of Cynara's

\footnotetext{
${ }^{103}$ SunTrust, 268 F 3d 1257, 1277 (11 ${ }^{\text {th }}$ Cir, 2001).

${ }^{104}$ Ibid 1269.

${ }^{105}$ Ibid.

${ }^{106}$ Ibid.

${ }^{107}$ Ibid.

${ }^{108}$ Ibid 1270.

${ }^{109}$ Ibid.
} 
fictional diary that Randall's work flips GWTW's traditional race roles, portrays powerful whites as stupid or feckless, and generally sets out to demystify GWTW and strip the romanticism from Mitchell's specific account of this period of our history. ${ }^{110}$

Viewed from this perspective the transformative nature of TWDG is undeniable. As such, the $11^{\text {th }}$ Circuit easily found that Randall had sought to transform Mitchell's work rather than to relieve herself of the burden of creating a new work. $^{111}$

Judge Birch effectively dismissed the second fair use factor on the grounds that though creative works such as GWTW were entitled to significant protection, parodies 'invariably copy publicly known expressive works' ${ }^{112}$ Similarly, in relation to the third fair use factor the $11^{\text {th }}$ Circuit noted that a parody must take at least enough of the original work to 'conjure up the original in the minds of the readership'. ${ }^{113}$

With regard to the fourth fair use factor the $11^{\text {th }}$ Circuit again found in favour of Randall and Houghton Mifflin. The Court noted that there was a market for sequels to GWTW, but it was plain that TWDG, which addressed 'miscegenation' and homosexuality, did not fit with that market. In sum, SunTrust failed to adduce evidence to suggest that TWDG would supplant the market for sequels to GWTW. ${ }^{114}$ Though the scathing parody might have suppressed demand for the original through its criticism, it was not involved in seeking to acquire the same market through mimicry.

The decision in SunTrust ${ }^{115}$ is heartening because it preserves speech that challenges prejudice and stereotypes. The Court obviously drew heavily on the Supreme Court's decision in Campbell in making its finding of fair use. There are two observations that can be made of SunTrust. First, the close alignment between the reasoning of the $11^{\text {th }}$ Circuit and the Campbell Court suggests that a somewhat rigid framework for parody cases may be emerging. This should be related back to the point that Samuelson made in her study of fair use, that nonparodic transformative uses can also be fair uses. Not every type of literary rewrite will fit the template created in SunTrust and Campbell, but this should not preclude a finding of fair use. Secondly, a finding of fair use was far from a certainty. After all, in the District Court, Judge Pannell had looked at the same

\footnotetext{
${ }^{110}$ Ibid.

${ }^{111}$ Ibid 1271 citing Campbell, 510 US 569, 580 (1994).

112 Ibid 1271 citing Campbell, 510 US 569, 586 (1994).

${ }^{113}$ Ibid 1272.

${ }^{114}$ Ibid $1275-6$.

${ }^{115}$ SunTrust, 268 F 3d 1257, 1277 (11 ${ }^{\text {th }}$ Cir, 2001).
} 
facts and had drawn the conclusion of unfairness and infringement. Fair use cannot shake its inherent uncertainty as it needs to be evaluated on a case-bycase basis. Moreover, our judicial system, replete with its appellate review, only adds to that uncertainty. It seems trite to observe that there are no better alternatives to our longstanding legal system and uncertainty may well be the price to be paid for flexibility.

\section{B Sixty Years Later and Salinger v Colting}

It is somewhat ironic that in an iconic passage from Catcher in the Rye, the narrator recounts being told by his literature teacher that many men before him had kept a record of their troubles from which a young and troubled Holden Caulfield could learn. The teacher suggested that Holden could one day write down his own experiences and referred to it as 'a beautiful reciprocal arrangement'. ${ }^{116}$ When one considers the utilitarian ideals underpinning copyright, then JD Salinger's travails in copyright law seem a snub to the reciprocity embedded in copyright's rationale. ${ }^{117}$ The late JD Salinger used his copyright to shut down an unauthorised biography and Colting's novel 60YL.

Colting wrote 60YL as a sequel to Catcher in the Rye. However, in 60YL, Colting portrayed Holden Caulfield, ' $\mathrm{Mr} \mathrm{C}^{\text {' }}$ in the novel, as an aged 76-year-old roaming around New York City. In 60YL instead of having been set loose from a high school, Holden had run away from a retirement home. In 60YL, Colting engineers a meeting between $\mathrm{Mr} \mathrm{C}$ and Salinger himself. The tone, language, and many of the characters from 60YL are similar to or are taken from Catcher in the Rye.

Salinger sued to prevent the publication of 60YL. The District Court found that 60YL was substantially similar to Catcher in the Rye. ${ }^{118}$ As such there was a prima facie case of copyright infringement. In relation to Colting's fair use argument the District Court found that 60YL did not contain sufficient parodic elements with regard to Catcher in the Rye. ${ }^{119}$ Similarly, the District Court held that $60 \mathrm{YL}$ was not adequately transformative in relation to the original work. ${ }^{120}$

\footnotetext{
${ }^{116}$ The exact quote is: 'Many, many men have been just as troubled morally and spiritually as you are right now. Happily, some of them kept records of their troubles. You'll learn from the - if you want to. Just as someday, if you have something to offer, someone will learn something from you. It's a beautiful, reciprocal arrangement. And it isn't education. It's history. It's poetry.' J D Salinger, Catcher in the Rye (Little, Brown and Company, 1951) 246.

${ }^{117}$ See Salinger v Random House Inc, 650 F Supp 413 (SDNY, 1986); Salinger v Random House Inc, 811 F 2d 90 ( $2^{\text {nd }}$ Cir, 1986); Salinger $v$ Random House Inc, 484 US 890 (1987).

${ }^{118}$ Salinger v Colting, 641 F Supp 2d 250, 254 (SDNY, 2009).

${ }^{119}$ Ibid 257-60.

${ }^{120}$ Ibid 261-2.
} 
The second and third factors were decided against Colting. ${ }^{121}$ In relation to the fourth factor the District Court found that as a 'sequel' to Catcher, 60YL could harm the market for an authorised sequel. ${ }^{122}$

Colting appealed the District Court's decision to the United State Court of Appeals for the $2^{\text {nd }}$ Circuit. The $2^{\text {nd }}$ Circuit remanded the case to the District Court with respect to the issue of the legal standard for injunctions. ${ }^{123}$ However, the $2^{\text {nd }}$ Circuit affirmed the District Court's ruling on the likely merits of Salinger's copyright claim. ${ }^{124}$ The District Court's findings in relation to the first factor were pivotal to the $2^{\text {nd }}$ Circuit's concurrence in Salinger $v$ Colting:

The District Court in its discussion of fair use focused on the first statutory factor: the 'purpose and character of the use' ... In doing this, the Court found that '[i]t is simply not credible for Defendant Colting to assert now that his primary purpose was to critique Salinger and his persona, while he and his agents' previous statements regarding the book discuss no such critique, and in fact reference various other purposes behind the book.' Such a finding is not clear error. ${ }^{125}$ [Citations omitted]

There was an obvious disconnect between the statements made by Colting and his publisher prior to the commencement of litigation and the arguments that he sought to rely on in his defence at trial. Prior to litigation Colting had suggested that 60YL was a sequel to Catcher, at trial he argued that the book was a commentary on the iconic status of Catcher and the relationship between the original author and the character Holden Caulfield. There was some merit to the argument run at trial and Colting was able to adduce two literary experts to support his claim. ${ }^{126}$ Nonetheless, it is pertinent that both Courts focused on the disjunct between his earlier statements and his defence, as this seemed to bring in the notion of 'unclean hands', an equitable concept, into the fair use analysis. While it was not addressed directly as an issue of 'unclean hands' the focus on conduct sits at odds with Leval's point that fair use, though often referred to as the 'equitable doctrine of fair use', is in fact a common law doctrine. ${ }^{127}$ As such, the question should simply have been whether 60YL as a literary work could come within the boundaries of fair use in its own right. This would have involved an examination of whether a parodic purpose or transformative use

\footnotetext{
${ }^{121}$ Ibid 263.

${ }^{122}$ Ibid 267-8. This was despite the fact that Salinger had not written a new work since Catcher in the Rye and was unlikely to write a sequel himself or to authorise one.

${ }^{123}$ Salinger v Colting, 607 F 3d 68, $84\left(2^{\text {nd }}\right.$ Cir, 2010).

${ }^{124}$ Ibid 83.

${ }^{125}$ Ibid.

${ }^{126}$ Ibid 72.

127 See Sony, 464 US 417, 448 (1984) where the Supreme Court referred to fair use as an 'equitable rule of reason'.
} 
could have been gleaned from the text of 60YL itself. However, given the District Court's finding that neither parody nor transformative use was sufficiently apparent in 60YL, it seems likely that a fair use defence would have failed notwithstanding any conjecture as to Colting's conduct.

\section{CAN FAIR USE WORK?}

Two cases do not make for a substantial sample from which to adjudge the relationship between the doctrine of fair use and literary re-writes. Yet, from the jurisprudence that we do have three observations may be made. First, fair use will favour free speech and literary re-writes if the second work is sufficiently transformative. Colting's main failure in 60YL was that his work was not sufficiently transformative. In contrast TWDG was greatly transformative. Secondly, fair use can offer little in the way of certainty. This is perhaps a structural problem pertaining to the doctrine as questions of fair use must be determined on a case by case basis and reasonable minds can disagree on the application of the doctrine. Thirdly, fair use offers enough flexibility to allow highly transformative works the space to exist as free use exceptions to copyright infringement. It is this last observation that makes fair use still a somewhat desirable presence in Australian copyright law.

Australia eschewed fair use when it enacted the Copyright Amendment Act 2006. The then Attorney-General, Philip Ruddock MP stated in 2007 that fair use 'could cause confusion and uncertainty if introduced here'. ${ }^{128}$ However, when viewed as a doctrine that applies to different clusters of like-cases there seems to be less uncertainty in fair use than first appears. Moreover, the doctrine is broader in its scope than ss $41 \mathrm{~A}$ and 103AA of the Copyright Act, and they have at least the advantage of a substantial body of jurisprudence from the United States. The large amount of US jurisprudence is appealing notwithstanding the difficult task of translating that into Australian law, particularly in light of a different constitutional context.

It is beyond the scope of this paper to enquire deeply into the meaning of ss $41 \mathrm{~A}$ and 103AA of the Copyright Act. Suffice to say, it is not impossible that the fair dealing provisions of the Australian statute might support literary re-writes. It is also premature at this point to advocate any particular rule for adoption into Australian law though I would make the point that fair use should not be discounted too easily. Nonetheless, there is significant cultural and social value in protecting literary re-writes as either fair uses or fair dealings. It is only to our disadvantage that we ignore the 'free use' interests of secondary authors who

\footnotetext{
${ }^{128}$ Philip Ruddock, 'Fair Use and Copyright in Australia' (2007) 25(2) Communications Law Bulletin 4, 6.
} 
might offer us creative re-writes of existing works. In allowing copyright to push out these authors we are denied the perspective that they may offer.

I am mindful that my essay here was first presented at Deakin University's Remix Conference and that it must speak in some way to the broader issues surrounding remix culture. I think that the fundamental point about remix culture and its interaction with copyright law was made by Lessig in his text on remix - namely that remix culture has become a way of life for the digital natives of Gen Y and the like and that our existing laws either criminalise or impose liability upon their creativity. Intuitively, this seems wrong - culture is after all a shared experience. And dividing society up into creative classes and consuming classes when that rigidity need not exist is unnatural. The re-write novel plays into this debate in much the same way. Authors will always build upon what came before them. Further, whether that involves commenting on racial inequality and prejudice or literary fame and isolation, these re-writings offer something invaluable to our broader culture. Moreover, they take more effort than a brief YouTube clip. To allow copyright to foreclose or limit the space of the re-write novel is also to blur the line between the literary re-write and the plagiarist. As stated, this is unfair given that the literary re-write does not try and hide its relationship to the original work. To put the matter in free speech parlance, the literary re-write is concerned with the search for truth.

If the space does not currently exist, or, if it is surrounded by too much uncertainty, then the proper question would be how might it be effectively created? There is one simple way. If fair use is brought into Australian law, and this might still happen, then the categories to which it might apply can be delineated within the statute itself. Moreover, where the category of free speech and transformative critiques are concerned, the statute can be worded so as to create a presumption in favour of fair use.

\section{CONCLUSION}

Copyright law is a crowded space full of different disputes and policy problems. Nevertheless, it is a body of law that sits within a wider legal system that serves a liberal democracy. That democracy does have an interest in constructive exercises of speech. That interest should have some part to play in copyright law. We need to be proactive in developing legal rules that suit the type of information culture that we desire. The greatest argument that might be made in favour of fair use is that, if it has succeeded in the United States in protecting literary re-writes, where that protection was demonstrably deserved, then it might play the same role in Australia, notwithstanding the untested nature of the recent parody and satire amendments. 